\title{
Sacred Groves: The Consequence of Traditional Management
}

\author{
Arpita Vipat and Erach Bharucha \\ Institute of Environment Education and Research, Bharati Vidyapeeth University, Pune 411030, India \\ Correspondence should be addressed to Erach Bharucha; arpita_iifm14@yahoo.com
}

Received 4 September 2014; Accepted 21 October 2014; Published 10 November 2014

Academic Editor: Kaushik Bose

Copyright (C) 2014 A. Vipat and E. Bharucha. This is an open access article distributed under the Creative Commons Attribution License, which permits unrestricted use, distribution, and reproduction in any medium, provided the original work is properly cited.

\begin{abstract}
The Western Ghats are one of the globally recognized "hot spots" of biodiversity in India. In Maharashtra small patches of forest in the Ghats are protected by local people as "sacred groves." They are called "Devrai" which have been managed by local people and are dedicated to the deity in the grove. These groves act as benchmarks of less disturbed vegetation. The study has been conducted on fifteen groves through detailed expert and semistructured interviews of their priests and locals have been conducted to appreciate their traditional management systems. There is no evidence to show that the groves were intended primarily for biodiversity conservation or as a science based natural resource management strategy. Biodiversity conservation of groves is thus a by-product of a traditional belief of locals in the supernatural power of the forest deity. The concept of ICCAs (Indigenous Community Conserved Areas) and making registries of local knowledge of biodiversity as a tool for developing future conservation initiatives can act as a useful strategy to preserve the groves in the face of regional development pressures and gain government recognition for protecting the groves in the long term.
\end{abstract}

\section{Introduction}

Traditional knowledge has been used for centuries by indigenous local communities to manage natural resources under local laws, customs, and traditions [1]. Many traditional societies all over the world revere and worship nature and consider certain plants and animals sacred. The sacred groves in the Western Ghats are small patches of ancient forest dedicated to local animistic deities [2,3]. These groves are a rich source of fruit bearing trees and small water bodies and act as habitat for several birds and reptiles. Resource extraction in the groves is limited by a variety of rules to placate the deity. This has resulted in the development of relict patches of climax forest [4]. Cultural and biological diversity is even today relevant as a tool for nature conservation [5] that is foremost for sacred grove conservation in Maharashtra.

The Western Ghats of India are one of the 34 globally important biodiversity hot spots [6, 7]. In 2006 the Western Ghats were proposed as a protected "World Heritage Site" and this has now been accepted by UNESCO. Mulshi District nested in the Ghats is a key site for conservation action. In Maharashtra the "sacred groves" in the Ghats which are locally called "Devrai" are key hot spots of biological diversity.
The Devrai word came from two local words; that is, Dev means God and rai means forest. So it means god's forest is Devrai. Such forest patches are considered a sacred forest by locals so they are called sacred groves. The groves thus act as key benchmarks of less disturbed vegetation in a mosaic of other traditional and modern forms of land use. The groves play a role in maintenance of the local ecological balance, conservation of watersheds, and preservation of bioresources. Sustainable use of resources and use of management principles for different landscape elements are frequently linked to culturally distinct sentiments.

In the villages in which groves are protected, regionally relevant folk knowledge supports traditional conservation practices. Local people have evolved their own traditional rules and management based on ancient practices which led to conservation and maintenance of the groves as relatively intact patches of forests as a by-product of their religious sentiments [8]. During the last two decades farmers have sold large pieces of land to speculators for urbanization. This is due to the enormous rise in the price of land. This change has triggered several socioeconomic and cultural aspects in the region with a consequent loss of protective sentiments for the sacred groves. 
TABLE 1: Location of fifteen sacred groves in Mulshi.

\begin{tabular}{|c|c|c|c|c|c|}
\hline Sr. number & Name of the grove & Name of the deity & Village & Location & Present status \\
\hline 1 & Dhigiaairai & Dhigiaai devi & Bhiravwadi & $\begin{array}{l}18^{\circ} 32^{\prime} 22.33^{\prime \prime} \mathrm{N} \\
73^{\circ} 30^{\prime} 58.66^{\prime \prime} \mathrm{E}\end{array}$ & $P$ \\
\hline 2 & Waghjai & Waghjai devi & Sonarwadi & $\begin{array}{l}18^{\circ} 32^{\prime} 26.50^{\prime \prime} \mathrm{N} \\
73^{\circ} 30^{\prime} 59.68^{\prime \prime} \mathrm{E}\end{array}$ & $\mathrm{P}$ \\
\hline 3 & Rai & Waghjai devi & Wadwathar & $\begin{array}{l}18^{\circ} 33^{\prime} 0.47^{\prime \prime} \mathrm{N} \\
73^{\circ} 29^{\prime} 29.26^{\prime \prime} \mathrm{E}\end{array}$ & Th \\
\hline 4 & Waghjairai & Waghjai devi & Chandiwali & $\begin{array}{l}18^{\circ} 35^{\prime} 9.53^{\prime \prime} \mathrm{N} \\
73^{\circ} 28^{\prime} 4.47^{\prime \prime} \mathrm{E}\end{array}$ & Th \\
\hline 5 & Firnangairai & Firnangai devi & Sarole & $\begin{array}{l}18^{\circ} 25^{\prime} 41.18^{\prime \prime} \mathrm{N} \\
73^{\circ} 23^{\prime} 24.72^{\prime \prime} \mathrm{E}\end{array}$ & $\mathrm{P}$ \\
\hline 6 & Firnangairai & Khagjai devi & Sarole & $\begin{array}{l}18^{\circ} 25^{\prime} 41.18^{\prime \prime} \mathrm{N} \\
73^{\circ} 23^{\prime} 24.72^{\prime \prime} \mathrm{E}\end{array}$ & $\mathrm{P}$ \\
\hline 7 & Kalkairai & Kalkai devi & Kondether & $\begin{array}{c}18^{\circ} 23^{\prime} 52.36^{\prime \prime} \mathrm{N} \\
73^{\circ} 23^{\prime} 56.18^{\prime \prime} \mathrm{E}\end{array}$ & Th \\
\hline 8 & Vinjai rai & Vinjai devi & Tamini & $\begin{array}{c}18^{\circ} 26^{\prime} 25.72^{\prime \prime} \mathrm{N} \\
73^{\circ} 25^{\prime} 39.17^{\prime \prime} \mathrm{E}\end{array}$ & $\mathrm{P}$ \\
\hline 9 & Kalubai chi rai & Kalubai & Lavarde & $\begin{array}{l}18^{\circ} 23^{\prime} 6.89^{\prime \prime} \mathrm{N} \\
73^{\circ} 29^{\prime} 15.17^{\prime \prime} \mathrm{E}\end{array}$ & $\mathrm{D}$ \\
\hline 10 & Bhiruoba cha ran & Bhiruoba & Lavarde & $\begin{array}{c}18^{\circ} 21^{\prime} 32.78^{\prime \prime} \mathrm{N} \\
73^{\circ} 30^{\prime} 0.09^{\prime \prime} \mathrm{E}\end{array}$ & Th \\
\hline 11 & Kanguram & Kangur maharaj & Kanguram & $\begin{array}{c}18^{\circ} 24^{\prime} 25.22^{\prime \prime} \mathrm{N} \\
73^{\circ} 30^{\prime} 57.28^{\prime \prime} \mathrm{E}\end{array}$ & Th \\
\hline 12 & Kanguram & Waghjai & Kanguram & $\begin{array}{l}18^{\circ} 24^{\prime} 23.46^{\prime \prime} \mathrm{N} \\
73^{\circ} 30^{\prime} 53.36^{\prime \prime} \mathrm{E}\end{array}$ & $\mathrm{P}$ \\
\hline 13 & Kolavade rai & Bhiravnath & Kolavade & $\begin{array}{l}18^{\circ} 27^{\prime} 18.66^{\prime \prime} \mathrm{N} \\
73^{\circ} 33^{\prime} 30.93^{\prime \prime} \mathrm{E}\end{array}$ & Th \\
\hline 14 & Kharavade rai & Mhasoba & Kharavade & $\begin{array}{l}18^{\circ} 27^{\prime} 15.33^{\prime \prime} \mathrm{N} \\
73^{\circ} 35^{\prime} 26.80^{\prime \prime} \mathrm{E}\end{array}$ & $\mathrm{D}$ \\
\hline 15 & Vandev rai & Vanoba & Temghar & $\begin{array}{l}18^{\circ} 23^{\prime} 29.86^{\prime \prime} \mathrm{N} \\
73^{\circ} 30^{\prime} 40.30^{\prime \prime} \mathrm{E}\end{array}$ & $\mathrm{D}$ \\
\hline
\end{tabular}

P: protected, Th: threatened, and D: destructed.

\section{Methods}

This study has been carried out in and around the sacred groves of Mulshi region in Maharashtra. The research data has been collected through transects walks and discussions with local people. Seven detailed expert interviews with local priests and ninety-three semistructured interviews were carried out with elders and local village folk, to understand the local relevant institutional management used for protecting their sacred groves. Semistructured interviews are the ones that have a flexible and fluid structure, unlike structured interviews that have a prepared sequence of questions to be asked in the same way of all interviewees [9]. The semistructured interviews can modify or deflect from topic as per the requirement of study. During the interviews mostly the locals diverted from the topic but the given information was also useful. So in such case the formal interviews sessions were avoided and we had supple interview session with the locals.

The fifteen sacred groves studied are linked to tribal deities and often occur in inaccessible areas at higher elevations near the crest line of the Ghats at a considerable distance from the villages (Table 1). Among the fifteen sacred groves, ten are dedicated to female deities and five to male deities. The female deities of the groves are unshaped stones painted with red color (sindhur) and the male deities are often roughly sculpted black stone figures. The names of the animistic deities are frequently related to the ferocious tigers or tigresses that once roamed these forests which had to be appeased.

Each village is located around their sacred grove. So that villagers can access the grove for worship and resource extraction. The tribal communities Dhangar and Mahadeo Koli and the agropastoral community Maratha worship the deities and look after the groves. They are forest dependent communities and Marathas carry out agricultural practices. Dhangar and Mahadeo Koli survive by extracting forest resources and sometimes also work on agricultural field of Marathas, such as on their agricultural field, and take care of their cattle.

Transect walks were made with local stakeholders to study the utilization of resources from the groves which are commonly collected by local communities for consumptive and productive uses from within and outside the grove. The knowledge of the resources that can be collected from the groves and those that are considered taboo is spread from one 
person to another without any written rules. The groves vary from one to eight hectares in size but are occasionally much larger. The forest patches contain a rich repository of plant species, massive old trees, covered with lianas and climbers. They are frequently associated with an emergent stream and have better soil as compared to adjacent areas.

\section{Result}

The groves have not been measured or demarcated by the Forest Department, Revenue Administration, or by the local Panchayats (local government). This makes the boundary rather flexible and denoted only by the change in vegetation. There was no evidence to show that the groves were maintained for their biodiversity conservation potential or for protecting their natural resource for the future. The preservation of groves is a result of strong ancient beliefs that any damage to the grove would anger the deity who would take revenge on the intruder who desecrates its integrity. In Mulshi most groves cannot be entered by local women. Incidentally women are the main resource use collectors in this region and this norm may act as an additional protection against overexploitation of resources within the groves.

Levels of sustainability: the assessment of sustainability of a grove in terms of economic, social, and environmental (ecological) parameters is depicted in Table 2. This has been considered in terms of the different local consumptive and productive uses of resources and ecological services provided by the grove. There has been a perceptible loss of protective sentiments and religious perceptions of local people towards the preservation of these groves during the last couple of decades. New strategies for their management must thus attempt to drive unsustainable practices towards sustainable levels through locale specific management by enhancing local community initiatives if the groves are to be conserved in the future.

\section{Discussion}

Need for conservation of sacred groves: most authorities in the past [10] and others emphasized that extraction of resources from the grove was strictly prohibited. This is not so today in the groves of the Mulshi District where development in the form of land use change is increasing rapidly over the last decade. These groves are important today as they are potential banks of genetic diversity that must be preserved. In the local context the sacred groves have ecological values, economic concerns, societal functions and use of traditional sacred rituals, and customs for management. The long term economic value of sacred groves is difficult to assess as it will only become overt when new uses are found for its rare and endemic species of flora and fauna. Conservation of sacred groves however acts as a contributor to maintenance of local and regional biodiversity and maintenance of the comprehensive health of a landscape and preservation of the sociocultural integrity of local communities $[4,11,12]$.

Policy and institutional aspects of resource management in the sacred groves: in the sacred groves resource use
Present status of sacred groves in Mulshi region of the Western Ghats

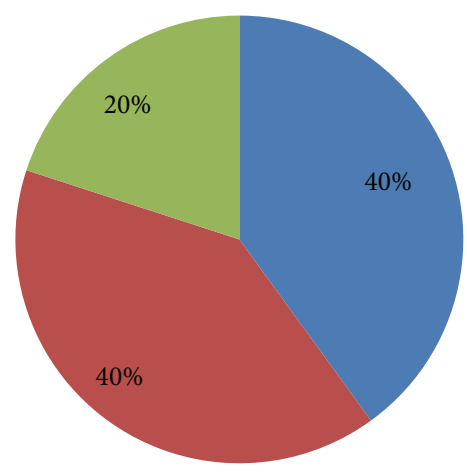

Protected

Threatened

Destructed

FIgURE 1: Present status of sacred groves in Mulshi region of the Western Ghats.

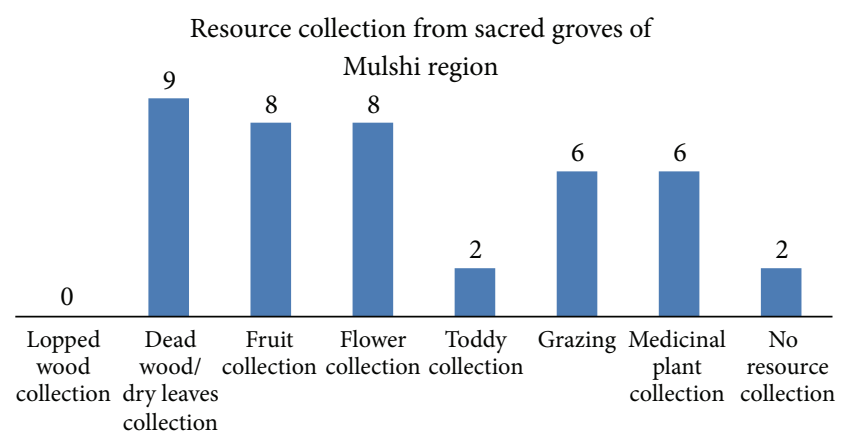

Figure 2: Resource collection from the fifteen sacred groves of Mulshi region.

is controlled by local institutional arrangements that have protected the groves through many generations. These norms are known not only to the presiding priests, but also to most of the villagers of all the different local communities in each village. This includes complete protection in one grove and partial protection in twelve groves (Figure 1). Two of the groves have been completely destroyed due to construction of a dam. For example, complete protection is observed in the Kalkai sacred grove where nothing can be taken or used. In the Bhiravwadi and Wadwathar groves "toddy" (liquor) is tapped. In the Kanguram sacred grove medicinal plants such as "ringni" is used to cure dental problems. From the eight groves fruits such as Mangifera indica and Artocarpus heterophyllus are collected. The seasonal collection of flowers from the grove includes overextraction of Curcuma elata, a flower used for rituals at the Ganesh festival. These flowers are extensively collected in eightgroves from August to October. In six of the groves grazing cattle is permitted. In nine groves dead fallen branches of the trees can be used as fuel wood (Figure 2).

Societal functions of sacred groves and local management concerns: there are local institutions and rules of behavior 
TABLE 2: Levels of sustainability of sacred groves.

\begin{tabular}{|c|c|c|c|c|c|c|}
\hline & \multicolumn{2}{|c|}{ Economic concerns } & \multicolumn{2}{|c|}{ Societal concerns } & \multicolumn{2}{|c|}{ Environmental (ecological) concerns } \\
\hline & Unsustainable & Sustainable & Unsustainable & Sustainable & Unsustainable & Sustainable \\
\hline \multirow{4}{*}{$\begin{array}{l}\text { Biodiversity } \\
\text { values (faunal } \\
\text { and floral) }\end{array}$} & $\begin{array}{l}\text { Destruction of } \\
\text { habitat and } \\
\text { poaching of species } \\
\text { for economic } \\
\text { reasons. }\end{array}$ & $\begin{array}{l}\text { Conservation of } \\
\text { indigenous plant } \\
\text { species for their } \\
\text { option value; } \\
\text { consumptive and } \\
\text { productive value of } \\
\text { resources. }\end{array}$ & $\begin{array}{l}\text { Exploitation by } \\
\text { outside people for } \\
\text { various uses such } \\
\text { as a picnic spot. }\end{array}$ & $\begin{array}{l}\text { Understanding the } \\
\text { concept of } \\
\text { intellectual } \\
\text { property rights } \\
\text { (IPR). } \\
\text { Sustainability of } \\
\text { resources by local } \\
\text { traditional forest } \\
\text { communities. }\end{array}$ & $\begin{array}{l}\text { Loss of biodiversity } \\
\text { at all levels, leading } \\
\text { to destruction of } \\
\text { sacred grove which } \\
\text { is responsible for } \\
\text { loss of overall } \\
\text { ecosystem } \\
\text { integrity. }\end{array}$ & $\begin{array}{l}\text { Need for better } \\
\text { management by } \\
\text { establishing } \\
\text { Community } \\
\text { Conserved Areas } \\
\text { (CCAs). }\end{array}$ \\
\hline & $\begin{array}{l}\text { Increasing cost of } \\
\text { land for } \\
\text { urbanization } \\
\text { overuse for } \\
\text { pharmaceuticals. }\end{array}$ & $\begin{array}{l}\text { Extraction of forest } \\
\text { products should be } \\
\text { limited to permit } \\
\text { adequate } \\
\text { regeneration. }\end{array}$ & $\begin{array}{l}\text { Wild flowers used } \\
\text { in rituals. }\end{array}$ & $\begin{array}{l}\text { Traditions that } \\
\text { safeguard the forest } \\
\text { should be } \\
\text { encouraged. }\end{array}$ & $\begin{array}{l}\text { Due to } \\
\text { deforestation and } \\
\text { degradation, the } \\
\text { biodiversity of the } \\
\text { area is adversely } \\
\text { affected. }\end{array}$ & $\begin{array}{l}\text { Stringent } \\
\text { implementation of } \\
\text { laws and } \\
\text { Biodiversity Act } \\
2004 \text {. }\end{array}$ \\
\hline & $\begin{array}{l}\text { Overexploitation } \\
\text { of forest products } \\
\text { for extensive use of } \\
\text { timber and } \\
\text { nontimber forest } \\
\text { product (NTFP). }\end{array}$ & $\begin{array}{l}\text { Carrying capacity } \\
\text { of the forests must } \\
\text { not be exceeded. }\end{array}$ & $\begin{array}{l}\text { Local people or } \\
\text { traditional forest } \\
\text { dwellers are } \\
\text { deprived of their } \\
\text { rights over the } \\
\text { forest. }\end{array}$ & $\begin{array}{l}\text { Limited use of } \\
\text { detritus for rural } \\
\text { energy. }\end{array}$ & & $\begin{array}{l}\text { Better } \\
\text { management } \\
\text { through local } \\
\text { involvement by } \\
\text { establishing CCAs. }\end{array}$ \\
\hline & & & & $\begin{array}{l}\text { Plantations of local } \\
\text { species. } \\
\text { Ecodevelopment of } \\
\text { surrounding } \\
\text { village. }\end{array}$ & & $\begin{array}{l}\text { Use of locale } \\
\text { specific } \\
\text { ecorestoration and } \\
\text { ecotourism to } \\
\text { reduce threat. }\end{array}$ \\
\hline $\begin{array}{l}\text { Surrounding } \\
\text { land use } \\
\text { (grazing, } \\
\text { fodder) }\end{array}$ & $\begin{array}{l}\text { Unsustainable } \\
\text { change in land use } \\
\text { pattern due to } \\
\text { short term } \\
\text { economic gain. } \\
\text { Land speculation. }\end{array}$ & $\begin{array}{l}\text { Land use pattern } \\
\text { should be such that } \\
\text { environmental } \\
\text { concerns are } \\
\text { addressed. }\end{array}$ & $\begin{array}{l}\text { No land for local } \\
\text { tribal-forest } \\
\text { dwellers who are } \\
\text { deprived of their } \\
\text { traditional rights } \\
\text { over the forest. }\end{array}$ & $\begin{array}{l}\text { Use of concepts } \\
\text { and programmes } \\
\text { like community } \\
\text { reserves, joint } \\
\text { forest management } \\
\text { (JFM), and } \\
\text { ecodevelopment. }\end{array}$ & $\begin{array}{l}\text { Loss of precious } \\
\text { biodiversity, } \\
\text { increase in } \\
\text { deforestation, } \\
\text { increase in } \\
\text { wastelands. } \\
\text { Urban sprawl } \\
\text { leading to poverty. }\end{array}$ & $\begin{array}{l}\text { Linkages to } \\
\text { regional Protected } \\
\text { Area Network; } \\
\text { ecorestoration of } \\
\text { degraded } \\
\text { landscape and } \\
\text { formation of } \\
\text { corridor forest. }\end{array}$ \\
\hline Agriculture & $\begin{array}{l}\text { Intensive } \\
\text { agriculture, } \\
\text { depending on cash } \\
\text { crops. Change in } \\
\text { cropping pattern } \\
\text { for short term } \\
\text { economic gain, for } \\
\text { example, } \\
\text { cultivation of } \\
\text { sugarcane and use } \\
\text { for Japanese } \\
\text { technique for rice } \\
\text { cultivation. }\end{array}$ & $\begin{array}{l}\text { Traditional } \\
\text { agricultural } \\
\text { systems that } \\
\text { permit a wide } \\
\text { range of produce to } \\
\text { be grown and } \\
\text { marketed } \\
\text { throughout the } \\
\text { year. }\end{array}$ & $\begin{array}{l}\text { Farmers receive } \\
\text { economic } \\
\text { incentives to grow } \\
\text { cash crops for } \\
\text { national and } \\
\text { international } \\
\text { market, rather than } \\
\text { to supply local } \\
\text { nutritional needs. }\end{array}$ & $\begin{array}{l}\text { Traditional hill } \\
\text { slope agriculture } \\
\text { (nachni, varai, etc.) } \\
\text { should be } \\
\text { encouraged as it is } \\
\text { an insurance } \\
\text { against the failure } \\
\text { of one crop. }\end{array}$ & $\begin{array}{l}\text { Reduction in soil } \\
\text { fertility due to } \\
\text { change in } \\
\text { traditional } \\
\text { techniques; high } \\
\text { risk of drought and } \\
\text { flood conditions, } \\
\text { desertification due } \\
\text { to overgrazing, fire, } \\
\text { change in land use } \\
\text { to urban settings. }\end{array}$ & $\begin{array}{l}\text { Mix crops or crop } \\
\text { rotation should be } \\
\text { practiced to } \\
\text { maintain the soil } \\
\text { fertility and proper } \\
\text { selection of the } \\
\text { crops depending } \\
\text { upon the soil } \\
\text { structure and } \\
\text { restriction of } \\
\text { grazing areas } \\
\text { should be } \\
\text { implemented. }\end{array}$ \\
\hline \multirow[t]{2}{*}{ Pilgrimage } & $\begin{array}{l}\text { Overexploitation } \\
\text { of fuel wood } \\
\text { during annual fest. }\end{array}$ & $\begin{array}{l}\text { Offer of money to } \\
\text { the deity which is } \\
\text { helpful for } \\
\text { maintenance of the } \\
\text { sacred grove. }\end{array}$ & $\begin{array}{l}\text { Enormous increase } \\
\text { in the number of } \\
\text { tourists and } \\
\text { pilgrims. }\end{array}$ & $\begin{array}{l}\text { Control on } \\
\text { negative activities } \\
\text { of tourists and } \\
\text { pilgrims. }\end{array}$ & $\begin{array}{l}\text { Solid waste } \\
\text { pollution of plastic, } \\
\text { wrappers, and so } \\
\text { forth. }\end{array}$ & $\begin{array}{l}\text { Ecotourism } \\
\text { training. }\end{array}$ \\
\hline & & & & & & $\begin{array}{l}\text { Initiatives for } \\
\text { local. }\end{array}$ \\
\hline
\end{tabular}


Present management authority of sacred groves in Mulshi region of the Western Ghats

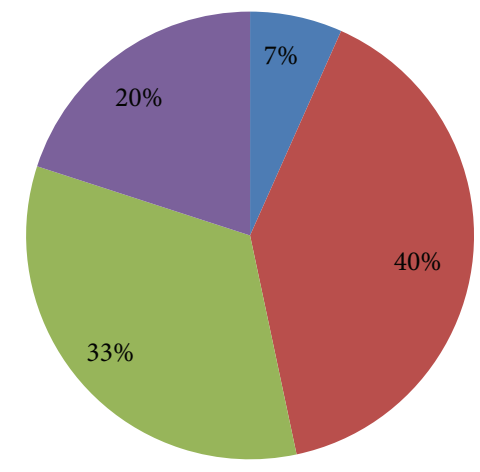

$$
\text { - Privately owned Temple trust }
$$$$
\text { - Community owned a Destructed }
$$

FIgURE 3: Present management authority of sacred groves in Mulshi region of the Western Ghats.

towards the sacred site which lead to resource preservation. The expert interviews which have been recorded from local priests emphasize the societal aspects rather than the management concerns of sacred groves. Ownership plays a vital role in local management (Figure 3 ). The grove land may be privately owned by an individual, family owned, common property of the village, panchayat (local government) lands, or recently created temple trusts. Cultural practices related to the sacred groves vary considerably. Among the fifteen sacred groves studied only one grove is privately owned which was bought in 1956 by the father of the present owner of the grove. In Tamini, Kharavade, and Kolavade villages, the local people have established temple trusts. The ownership of grove has an impact on resource use and level of protection as the trust is responsible for implementing local rules. It is also linked to other cultural aspects such as animal sacrifice and Kaul ceremonies. In case of Kharavade sacred grove, villagers have created trust for better management of sacred grove. These temple trusts act as extra income source for villagers. It is responsible for maintenance of the grove and management of pilgrims. They have constructed a bhakta niwas (lodge) for pilgrims in the adjacent villages. They take charges from pilgrims for providing a common facility to stay, drinking water, and sanitation. The money is used for maintenance of the temple. The trustee and members organize an annual fest for the deity. So such social gathering gives large amount of money from devotee. Presently the grove which was surrounded by trees is converted into a commercialized temple only. Generally the priest of the grove is the managing authority of the trust. So it is his beliefs and decision to make changes in the grove. For example, in the case of Chandiwali sacred grove the decision is based on local traditional ceremony Kaul. This ceremony is executed by local priests in front of the village deity to solve local problems. The villagers of Chandiwali wanted to construct a temple inside the grove. In order to take permission from deity the Kaul ceremony was conducted. In this ritual the deity is supposed to take correct decisions for the village. The priest places two beetle nuts or wheat grains in two water droplets that trickle down the side of the deity's platform. One grain of wheat is placed in the right trickle of water and another is placed in the left trickle. The objects are held to the side of the platform by surface tension of the water. The priest asks the deity for a "yes" or "no" response to a question. The question may be linked to permission to fell a tree or help in solving social or personal problems of villagers. If the right grain falls off the deity's platform first it is considered a good omen and the answer is a "yes." If the left falls first it is a bad omen and the answer is a "no." The villagers got left grain that means temple should not be constructed. Indirectly their beliefs save the forest because construction of temple will harm the whole forest patch. This ritual was performed frequently in the past and resulted in refusing permission for felling of trees in the grove. The stochastic chance would be about fifty percent. The younger Pujaries (priests) have stopped performing these ceremonies in the last two decades as they believe that the previous generation had divine powers which they do not possess.

Current threat: due to the developmental programs and land use change in the area the groves and their surrounds are being degraded. The whole Temghar village has been relocated due to the construction of Temghar dam. There was a large sacred grove in the area dedicated to the deity Vanoba (Van in the local language means "forest"). In Wadwathar and Kanguram village sacred groves have been fragmented due to construction of a tarred road passing through the groves. Among the fifteen sacred groves, three of the shrines have been converted into temple trusts in the recent past. Development of trusts for managing the groves is responsible for degradation of ancient traditional management systems. The traditional management system led to the conservation of indigenous knowledge as well the protection of biodiversity of the groves. The change is also responsible for an increase in the number of pilgrims from distant places. This results in unmanageable amounts of nondegradable solid waste, biodegradable garbage, and air and noise pollution inside the groves. In the past it was not possible to build a large temple as local traditional management insisted that it had to be completed overnight. It also required that a successful "Kaul" ceremony was done, and divine permission had to be obtained from the deity before construction.

During expert interviews the impacts of development on the sacred groves were discussed with local people. They mainly link the impacts on the groves to surrounding changes in the economics of land and resources that are driven by neighboring urban markets. The possible conservation strategies that could help to restore the "naturalness" of degraded sacred groves were discussed with local people, and their active participation has been assessed.

Ecological management: the existing management functions are usually cryptic and are not generally associated with managerial functions by the local community. Local people do not associate the groves with issues such as the need for biodiversity conservation or integrity of water resources. However, these "modern" surrogate values can be used to strengthen local support for groves that are being 
threatened by the increasing economic value of land and/or timber value sequestrated in the groves. The local people can be made aware of some of the ecological functions of the grove through an awareness campaign and a school education program. This must include the importance of biodiversity values, especially rare endangered threatened and endemic flora and fauna of the grove; the role of the grove in local sustainable land use management; functions related to water management and soil preservation; the economic potential as a gene pool of wild relatives of crops and the availability of seed banks of rare trees that are present in the grove. The role of the grove for microclimate control: the importance of carbon sequestration and the economic potential of the grove through sustainable tourism can be explained to local people to support management of the groves [13]. The sacred groves improve the soil stability of the area thus preventing erosion. Further these habitats maintain microclimate, enhance nutrient cycling, and can be used as a unique focus of in situ conservation. The sacred groves act as small less disturbed islands of vegetation and are an asylum for endemic and endangered plant and animal species [14]. The groves in Mulshi act as store houses of medicinal plants and wild plants that could help as sources of gene pools for cultivar varieties. These concepts must now be included in redrafting of management practice by the local community where necessary, as their traditional knowledge is not overtly linked to complex scientific foundations of ecological theory.

Biodiversity conservation management: expert interviews demonstrated that these management functions are not understood precisely by local people as the concepts are essentially not a part of their local traditional knowledge systems. If however modern concepts of conservation biology are explained in the local language these functions are easily appreciated. Most respondents agreed that the large groves of old growth signify near climax vegetation patterns and act as benchmarks of "naturalness." When all the species present in the fifteen small groves were surveyed for their species richness they together contain a majority of the species found in the region. The role of these small patches in ecosystem services like carbon sequestration, temperature control, and water conservation can be explained to local people for better management of the groves. Few studies on development strategies however endorse this role in biological or the potential ecological services of groves as being assets that local people can use sustainably. Being a part of relic forests, groves are repositories of ancient trees and undisturbed soils which play a pivotal role in sequestering considerable amounts of carbon [15]. Isolated small fragments may not have a great impact on regional temperature control on a large scale, but their role in maintaining the local climate near the ground cannot be ignored. This function protects and helps in preservation and regeneration of ecologically sensitive species. Local people knew that endangered species such as the giant squirrel which have disappeared from most parts of Mulshi are still found in some of the sacred groves. Studies on scattered trees in African savannas have shown that, due to interception of radiation and precipitation, they offer cooler microclimate in their surroundings, which act as shelter for many small organisms [16-18].
Future potential management strategies: if groves are being satisfactorily protected by local people, any intervention by the Forest Department, other government organizations, or NGOs may in fact become counterproductive. Thus careful studies of existing institutional mechanisms that have preserved the groves are required to be assessed and documented before any new interventions are instituted. The tabular way of strategies to study sacred groves has been shown in Figure 4. The level of intactness and extent of utilization of resources from the grove are prerequisites to development of rational future management strategies. However the concept of developing and managing ICCAs (Indigenous Community Conserved Areas), or creating Biodiversity Management Committees (BMC), and People's Biodiversity Registers (PBR) as registries of local biodiversity knowledge can act as a tool for assisting local communities to manage the groves proactively. These options may be used as new strategies without underplaying the spiritual importance of the groves. This would also permit gaining government recognition of their rights over biodiversity and recognition of their traditional culture.

The role of education and awareness for management of the sacred groves: the "role of education and awareness for conservation management of resources within the sacred groves" is a key component for the future sustainable management of the groves by local communities. The identification of specific groups of people or local functionaries is essential for conservation action. A major stakeholder group should be local school students as they form an important, enthusiastic, organized group to spread the need for conservation of the groves in the community. This would help in establishment of modern concepts of conservation in the villages by linking them to their own traditional knowledge. If sacred groves have to be conserved, younger generations should understand their importance both as a part of their traditional knowledge and through newer scientific approaches to biodiversity conservation at ecosystem, species, and genetic levels.

Local awareness strategies are to be looked at in terms of a temporal analysis by asking local people, especially the elderly respondents, about the traditional values that were enshrined in the grove and its deity in previous years. Studies have been made by asking them about the local folklore associated with the origins of the grove which have been described in their own words. Folk stories connected with an integral part of local myths and beliefs. This is now being lost due to the rapidly vanishing local sentiments and a decrease in the reverence level towards the deity which had once prevented loss of the "naturalness" of the groves.

\section{Conclusion}

The study reveals the strong local management strategies link between folk culture and their land for a variety of surrounding landscape elements. The management systems used at present in some groves permit a limited level of resource use to be extracted from the groves. This has permitted the sacred groves to develop into old growth forests of great antiquity. The residents of Mulshi interviewed during this study clearly 


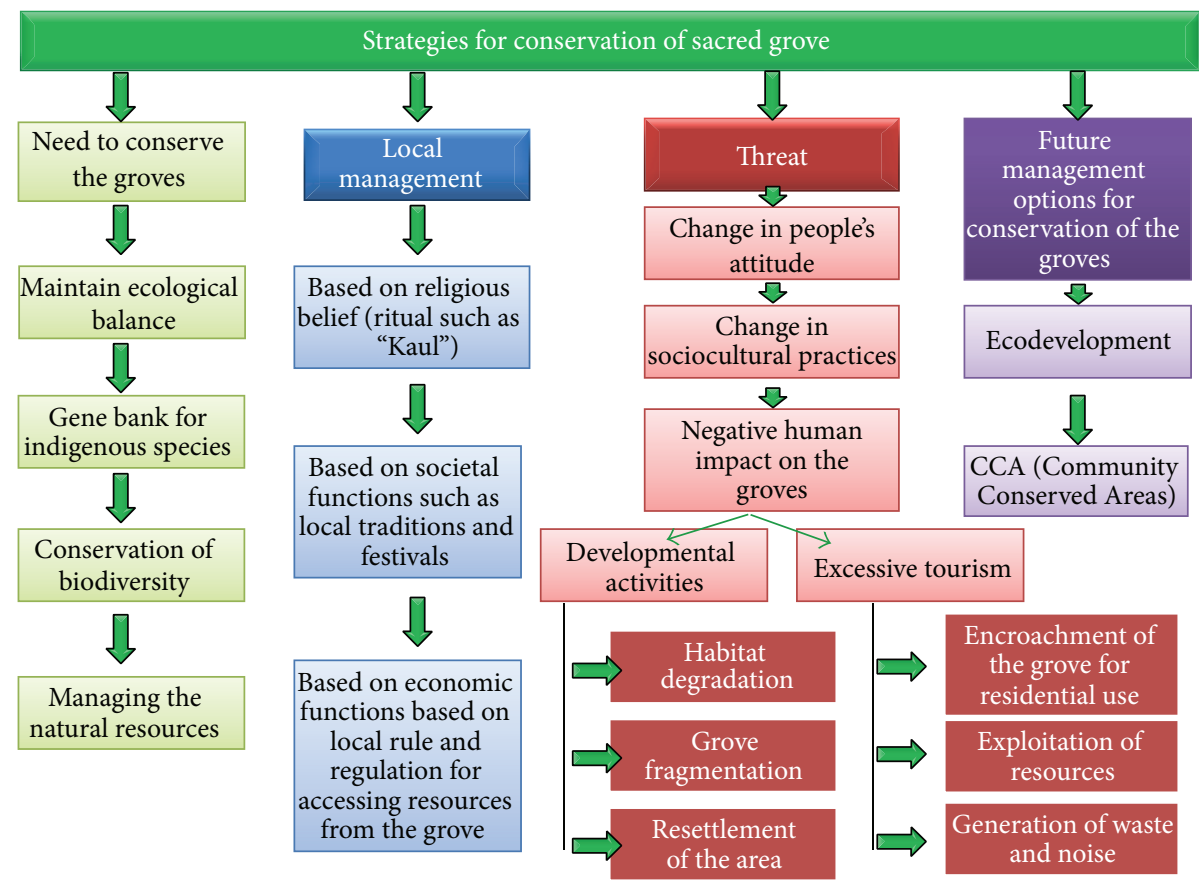

FIGURE 4: Strategies for conservation of sacred grove.

brought out their deep understanding of local forest resources as a life giving support system. However, they indicated that development has altered their perception due to the economic bonanza that land speculators have offered them over the last decade. The local myths, stories, and religious rituals are gradually being homogenized by external influences and the influx of towns' people and formal school education. Thus ceremonial rituals such as the "Kaul" that had a strong controlling influence on resource extraction from sacred groves are not practiced by the younger generation. The groves are slowly but surely being degraded or even severely damaged. An example is the complete destruction of the Lavarde grove which was an excellent example of a grove. The whole grove was felled to construct the Temghar dam. Thus the local management systems of the sacred groves are being gradually lost. The institutional local management structure based on respected priests and the integrity of the local village panchayat government is now being altered through a widening economic divide in the traditional community and through new societal changes. The traditional management of land and resource use patterns at the local level will be progressively lost as the farmland is converted to an intensively man modified urban landscape. Pros towards the groves are absent. Their values are linked to economic considerations or to superficial aesthetic concerns or for holidays and picnics. There is no respect for nature as a supporter of livelihoods which was a part of the lives of traditional agropastoral people. Finally appropriate management today must include identifying ways of using alternate conservation strategies for groves. Ecodevelopment, ecorestoration, and sustainable tourism, through registering local Biodiversity Management Committees, can prevent the destruction of the fragile and biologically rich ecosystems of the groves and their surrounds. Only strong locally relevant public opinion to conserve these regions fragile ecosystem and traditional cultural values can save the groves from ultimate annihilation.

\section{Conflict of Interests}

The authors declare that there is no conflict of interests regarding the publication of this paper.

\section{References}

[1] C. M. Correa, Traditional Knowledge and Intellectual Property, Quaker United Nations Office, Geneva, Switzerland, 2001.

[2] M. Gadgil and V. D. Vartak, "The sacred groves of Western Ghats in India," Economic Botany, vol. 30, no. 2, pp. 152-160, 1976.

[3] M. D. S. Chandran, M. Gadgil, and J. D. Hughes, Sacred Groves of the Western Ghats of India, 1992.

[4] A. Anthwal, N. Gupta, A. Sharma, S. Anthwal, and K.-H. Kim, "Conserving biodiversity through traditional beliefs in sacred groves in Uttarakhand Himalaya, India," Resources, Conservation and Recycling, vol. 54, no. 11, pp. 962-971, 2010.

[5] R. Ray and T. V. Ramachandra, "Small sacred groves in local landscape: are they really worthy for conservation?" Current Science, vol. 98, no. 9, 2010.

[6] C. Folke, "Traditional knowledge in social-ecological systems," Ecology and Society, vol. 9, no. 3, article 7, 2004.

[7] S. Molur, K. G. Smith, B. A. Daniel, and W. R. T. Darwall, The Status and Distribution of Freshwater Biodiversity in the Western Ghats, India, IUCN, Cambridge, UK and Gland, Switzerland, Zoo Outreach Organisation, Coimbatore, India, 2011. 
[8] K. C. Malhotra, S. Chatterjee, S. Srivastava, and Y. Gokhale, Cultural and Ecological Dimensions of Sacred Groves in India, Indian National Science Academy, 2001.

[9] J. Mason, "emistructured interview," in The SAGE Encyclopedia of Social Science Research Methods, pp. 1021-1022, SAGE Publications, Thousand Oaks, Calif, USA, 2004.

[10] M. Gadgil and V. Vartak, "Sacred groves of India: a plea for continued conservation," Journal of Bombay Natural History Society, vol. 72, pp. 314-320, 1975.

[11] S. Bhagwat, C. Kushalappa, P. Williams, and N. Brown, "The role of informal protected areas in maintaining biodiversity in the Western Ghats of India," Ecology and Society, vol. 10, no. 1, article 8,2008 .

[12] S. Bhagwat, C. Kushalappa, P. Williams, and N. Brown, "The role of informal protected areas in maintaining biodiversity in the Western Ghats of India," Ecology and Society, vol. 10, no. 1, article 8, 2005.

[13] S. A. Bhagwat and C. Rutte, "Sacred groves: potential for biodiversity management," Frontiers in Ecology and the Environment, vol. 4, no. 10, pp. 519-524, 2006.

[14] S. Chatterjee, A. R. K. Sastry, B. N. Roy, and R. Lahon, "Sacred groves of Sikkim and Arunachal Pradesh," in Abstract, National Workshop on Community Strategies on the Management of Natural Resources, Bhopal, India, 2000.

[15] M. L. Khan, A. D. Khumbongmayum, and R. S. Tripathi, "The sacred groves and their significance in conserving biodiversity an overview," International Journal of Ecology and Environmental Sciences, vol. 34, no. 3, pp. 277-291, 2008.

[16] S. Sukumaran and S. Jeeva, "A floristic study on miniature sacred forests at Agastheeshwaram, southern peninsular India," EurAsian Journal of BioSciences, vol. 2, p. 66, 2008.

[17] S. Sukumaran and A. D. S. Raj, "Evolution of sthalavriksha worship concept through the Sacred Groves in Kanyakumari District, Tamil Nadu, India," India. Journal of Basic and Applied Biology, vol. 2, no. 1, pp. 40-48, 2008.

[18] S. Sukumaran, S. Jeeva, A. D. S. Raj, and D. Kannan, "Floristic diversity, conservation status and economic value of miniature sacred groves in Kanyakumari district, Tamil Nadu southern Peninsular India," Turkish Journal of Botany, vol. 32, no. 3, pp. 185-199, 2008. 

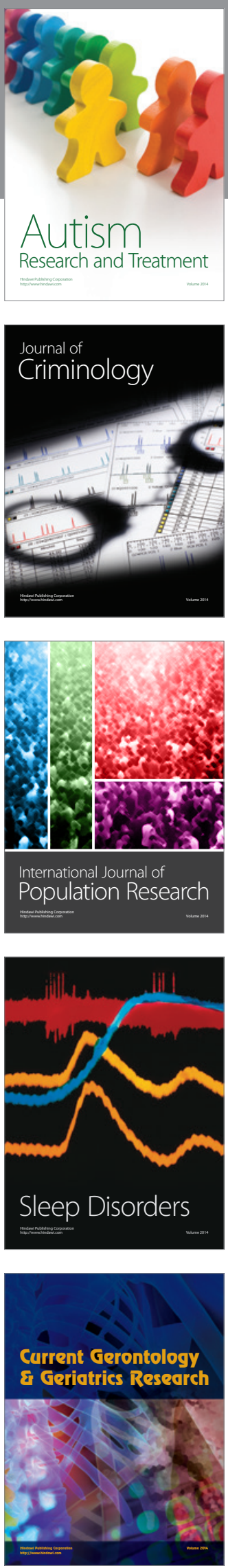
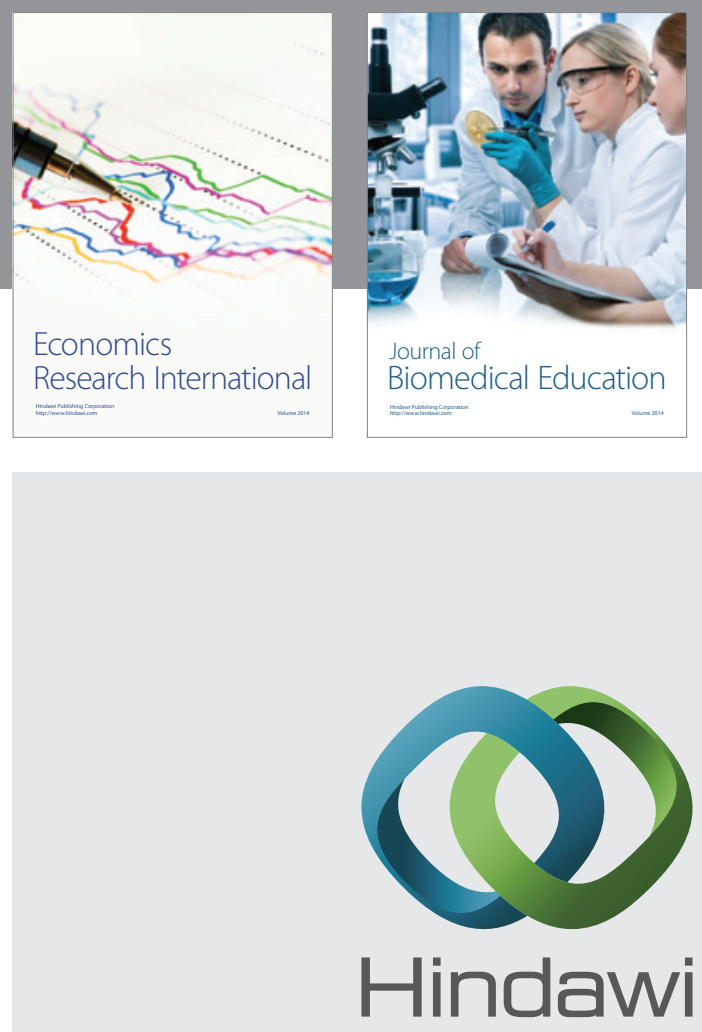

Submit your manuscripts at

http://www.hindawi.com
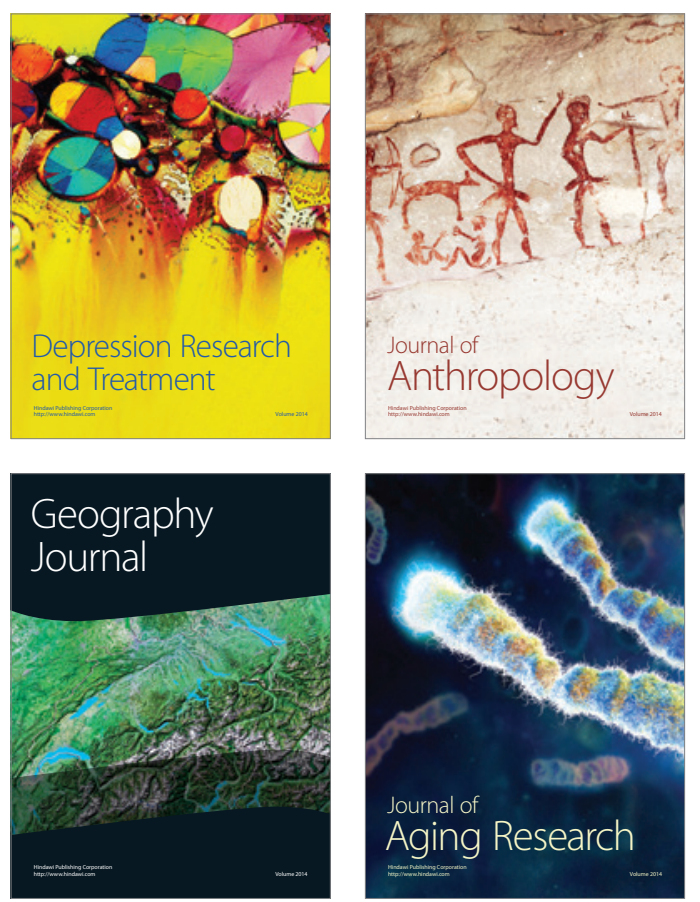
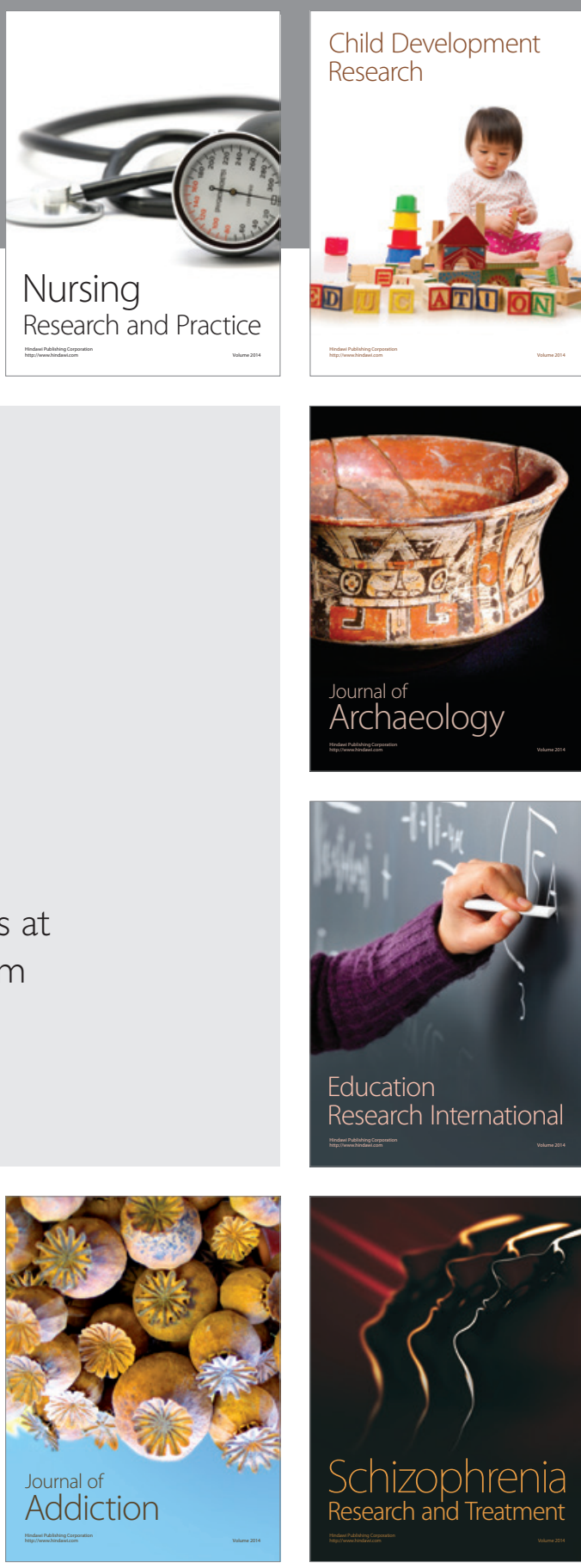

(D)
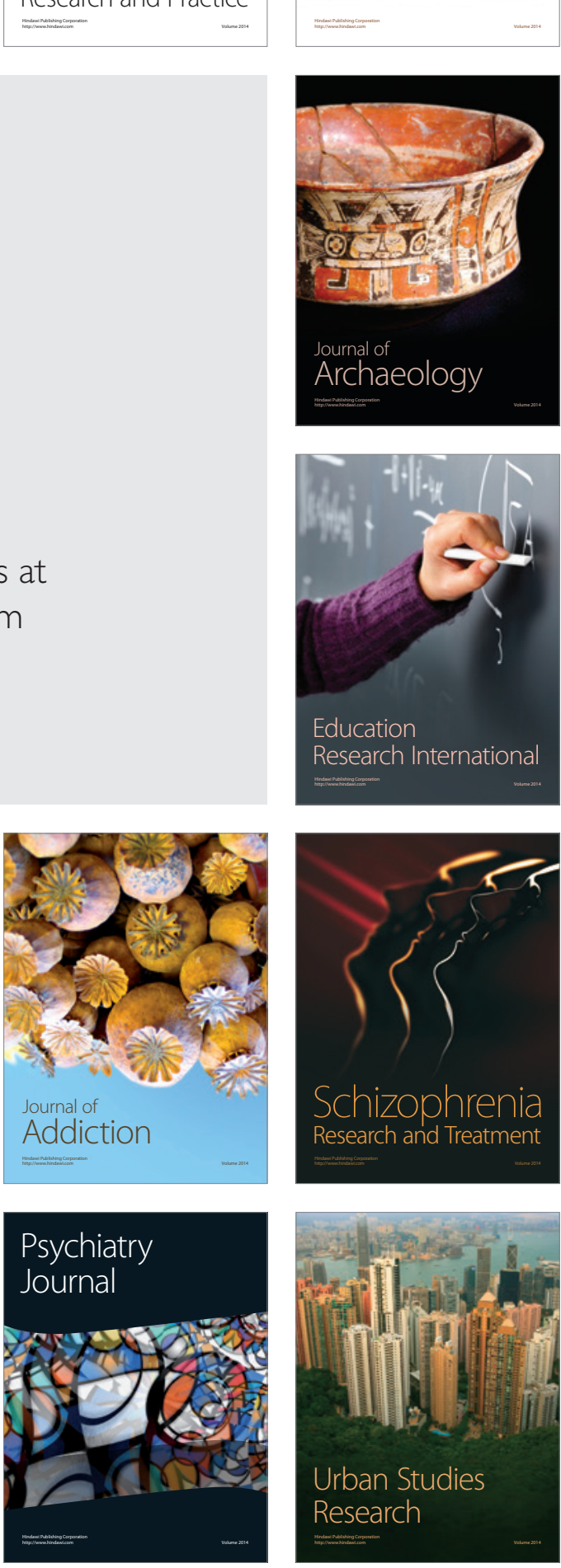